\title{
Moderna República velha um outro ano de $1922^{1}$
}

\section{Lilia Schwarcz ${ }^{2}$}

\section{Resumo}

O objetivo deste artigo é analisar diferentes recepções da jovem República, sobretudo em seus primeiros anos. Afinal, a tradição se inscrevia em meio à modernidade, e o novo se confundia com o velho. E é junto a esse caldo de paradoxos e conflitos que se desenha a Semana de Arte Moderna - um sopro de vanguarda, de cosmopolitismo e certo otimismo, nesse contexto - mas também outras experiências sociais de caráter mais político reivindicativo. Nesse sentido, ouso expor um pouco da experiência de Lima Barreto. Não para dela fazer um exemplo que ilumina toda uma época, ou muito menos "para estragar a festa" do ano de 2012. Ao contrário, ela representa um "outro caso", outra face da mesma modernidade. Quem sabe ela sirva como testemunho do ambiente que assolou parte da intelectualidade brasileira de inícios do século, cada vez mais descrente dos destinos dessa nação, e, nesse caso, muito impactados pelos discursos raciais deterministas, os quais, após a abolição da escravidão, criavam um novo tipo de "desigualdade", dessa feita pautada na biologia.

\section{Palavras-chave}

Lima Barreto, ciência, loucura, Primeira República

Recebido em 18 de abril de 2012

Aprovado em 6 de julho de 2012

SCHWARCZ, Lilia. Moderna República velha: um outro ano de 1922. Revista IEB, São Paulo, n. 55, p. 59-88, 2012.

I Este texto é pautado numa série de ensaios, de minha autoria, sobre Lima Barreto e a Primeira República. Agradeço Stelio Marras a uma série de comentários, todos acertados, sobre as práticas científicas à época.

2 Professora titular do Departamento de Antropologia da Faculdade de Filosofia, Letras e Ciências Humanas da Universidade de São Paulo (USP, São Paulo, SP, Brasil). E-mail: lilia.ms@uol.com.br 


\section{Modern old Republic \\ A different year of 1922}

\section{Lilia Schwarcz}

\section{Abstract}

The objective of this lecture is to analyze different impressions of the young republic, especially during its early years. After all, tradition confused itself with modernity, and the new and the old merged. And it was among these paradoxes and conflicts that the "Modern Art Week" took place- a blow of avant-garde, cosmopolitanism, and certain optimism in this context - but also other social experiences with a political vindication backdrop. In this sense, I dare to show some of the experience of Lima Barreto. I do not intend to make it an example that highlights an entire era, and even less "to spoil the party" of the year of 2012. Rather, it represents a "different case", a different face of the same modernity. Perhaps it serves as testimony to the atmosphere that devastated part of the Brazilian intellectuals from the beginning of the century, who were increasingly skeptical of the path this nation was taking, and in this particular case, were highly impacted by the discourse of racial determinists, who, after the abolition of slavery, began to establish a new type of "inequality", grounded in biology

Keywords

Lima Barreto, Science, Madness, First Republic 


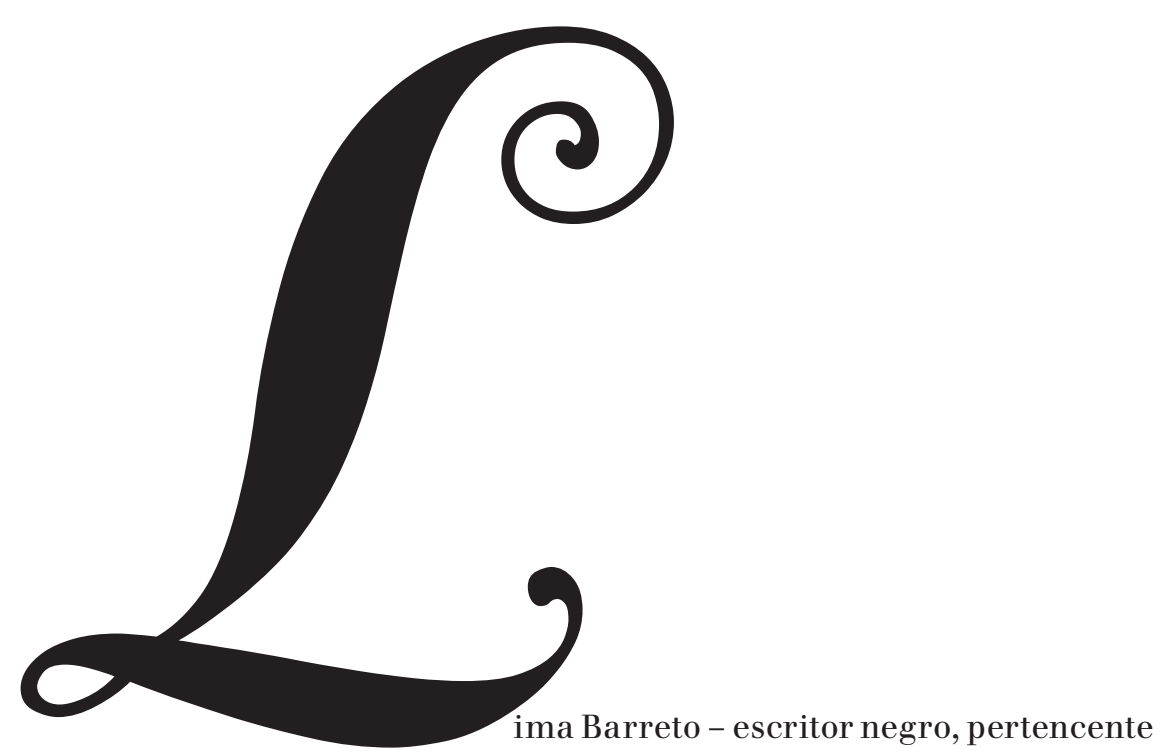
a uma classe média declinante e morador da periferia de Todos os Santos, próxima do centro charmoso e elegante do Rio de Janeiro, à época Capital Federal, morreu no mesmo ano de 1922. Ele que foi considerado por muitos como espécie de símbolo nervoso do contexto da Primeira República, foi assediado pelos modernistas paulistas, que viram nele um modelo alternativo ao da literatura da Academia Brasileira de Letras. No entanto, o literato carioca pareceu fechar essa porta.

Seu cenário era outro, aquele dos movimentos sociais, que tinham nas ruas e no espetáculo das multidões um ponto privilegiado de ação e agenda, mas também aquele que viu nascer discursos raciais e deterministas. De um lado, a nascente São Paulo transformou-se em teatro para as experimentações das vanguardas artísticas modernistas, de outro lado, deu guarida às novas tecnologias raciais de identificação e de condenação da mestiçagem. No Brasil conviveram, pois, liberalismo com darwinismo racial, inclusão com exclusão social, livre arbítrio com determinismo biológico e social.

Momento caracterizado por grandes paradoxos sociais, o contexto foi marcado por reações em tudo distintas. Visto sob determinado ângulo, a Primeira República significou, de fato, um momento de institucionalização cidadã, acolheu a inclusão social e presenciou a eclosão de uma série de movimentos sociais. No entanto, e sob outra esquina, foi também nesse período que uma série de projetos científicos, capitaneados pelas faculdades de medicina da Bahia e do Rio de Janeiro, assim como a voga do determinismo racial passaram a limitar biológica e cientificamente a ação do indivíduo e a própria noção de cidadania. Aí reside, por exemplo, o dilema de certos intelectuais negros que tentavam combater o racismo 
científico, mesmo que recorrendo politicamente à noção de raça. Autores como Luis Gama, Manuel Querino, José do Patrocínio, André Rebouças, Lima Barreto, raros nesse contexto em que "apagar a cor" era medida cautelosa e necessária, acabaram por viver em permanente dilema, conflito e contradição entre a projetada inclusão e a realidade da exclusão social. Além do mais, não poucas vezes, intelectuais como eles tentaram diferenciar-se de seu grupo de origem, por vezes declarando uma situação educacional e formação ímpares, por vezes lembrando de seu local em tudo singular como escritores, jornalistas ou ativistas sociais. Ou seja, esses intelectuais negros ou mestiços tentavam escapar do naturalismo (o dado biológico), confrontando-o com o construtivismo (educação, esforço de culturalização). Quer dizer, aí mesmo temos o debate sobre preeminências: se da Natureza ou se da Sociedade. Seja como for, desse dualismo ninguém que se inscreva na modernidade ou no Ocidente escapa. São de fato recursos críticos, cujo acento varia historicamente. Há, pois, um movimento de aproximação e de distanciamento importante a anotar, uma espécie de identidade partida entre natural e social, dado e construído, inato e adquirido, biológico e social, hereditário e ambiental, ação de dentro e ação de fora, semelhantes ao fenômeno que o sociólogo Paul Gilroy definiu quando tratou dessa espécie de “diáspora negra”, tão própria dos países que vivenciaram longos processos de escravidão.

O fato é que todo o panorama otimista, que antecedeu e abraçou a República, a partir dos anos 1910, fazia lembrar o fenômeno que Hannah Arendt chamou de "a era da assimilação", quando em diferentes regiões do mundo - com a experiência moderna da emancipação e da assimilação, que teve início já no contexto da Revolução Francesa - experimentou-se uma espécie de suspensão das restrições de fundo legal, moral, político e social, tradicionalmente vigentes. Tal situação levou a um sentimento bastante generalizado, de que era possível "erguer-se da escravidão", "sair do gueto", liberar-se do isolamento e acreditar na promessa da inclusão e da mobilidade ascendente. Ou a ideia de que o homem faz o seu destino (construcionismo ou sociologismo) e não o destino faz o homem (naturalismo ou biologismo). Essa parecia ser mesmo uma nova era em que, findas as formas de trabalho escravo e mandatório, e abertas (por meio da educação) as possibilidades de acesso à cidadania e novas formas de inclusão, imaginou-se um novo mundo, não mais cerceado por modelos de hierarquia social estrita, ou restrições de origem ou nascimento.

No entanto, esse cenário seria convulsionado pela entrada dos racismos e teorias raciais de toda ordem, que impuseram novas divisões entre os grupos humanos, agora justificadas por argumentos e teorias vindas da biologia. O resultado foi, na feliz e dolorida expressão 
de Leo Spitzer, em seu livro Vida de entremeios, um novo "embaraço da marginalização". Em vez da trajetória assimilacionista, que se apresentava como estrada de percurso longo, mas possível, deu-se a retomada de um projeto hierárquico, agora pautado na diferenciação racial, que passou a se apresentar tal moeda corrente. Como mostra o antropólogo Louis Dumont, o racismo emerge em finais do século XIX, justamente num mundo em que a percepção hierárquica das classes cede lugar a um ideário mais igualitário. Tratou-se, pois, de uma grande reversão de expectativas, diante de um contexto que parecia até então se apresentar como uma sociedade aberta, evolutiva, a oferecer uma miríade de possibilidades de inserção e identificação com uma ordem social consolidada em classes, e na crença internacional de que a cultura e a educação eram o principal veículo para a abolição das travas da escravidão e demais processos de servidão compulsória. Como mostram Jay Gould e Stocking Jr., se o evolucionismo deu um lugar para "os selvagens", integrando-os a uma escala evolutiva, mas numa mesma humanidade, coube ao darwinismo racial a exclusão de largos grupos, agora considerados "decaídos", "degenerados", mais conformados para a criminalidade e a loucura ${ }^{3}$.

O fato é que no Brasil, durante meados para final do século XIX, indivíduos outrora excluídos, por conta da cor ou da origem sociais, passaram a ter acesso a diferentes instituições de consagração e a galgar posições mais elevadas na hierarquia política do Império. Tudo parecia sinalizar para uma integração sem obstáculos ou barreiras intransponíveis. Mas tal abertura social - mais reconhecida em finais do século XIX - seria freada por novos critérios de alteridade racial, religiosa, étnica, geográfica, sexual e biológica. Aí estavam marcadores sociais de diferença dos mais vigorosos, porque moldados por critérios considerados racionais e objetivos, que agora faziam grande sucesso. Esse era um novo racismo científico, que acionava uma pletora de sinais físicos a definir a inferioridade e a falta de civilização, assim como estabelecia-se uma ligação agora obrigatória entre aspectos "externos" e "internos" dos homens. Narizes, bocas, orelhas, cor de pele, tatuagens, expressões faciais e uma série de "indícios" eram rapidamente transformados em "estigmas", definidores da criminalidade e da loucura, considerada uma "epidemia", disseminada por entre a população mestiçada. O resultado foi a condenação generalizada de largos setores da sociedade, dentre

3 Vide Stocking Stephen Jay Gould. The mismeasure of man. New York: Norton \& Company, 1981. George W. Stocking Jr. Race, culture, and evolution. Essays in the history of anthropology. Chicago: University of Chicago Press, e Bones, bodies, behaviour. Essays on biological anthropology. Wisconsin: University of Wisconsin Press. V. 5 . 
negros, mestiços e também imigrantes. Médicos e juristas, inspirados pela antropologia criminal de Cesare Lombroso, passavam a interferir na idealização do novo Código Penal, o qual, tendo por base essas novas tecnologias humanas, passava a ser entendido menos como um domínio do Direito ou do Jusnaturalismo - agora acusados de matéria para a metafísica e para a subjetividade da história aleatória - e mais como matéria para darwinistas sociais, acostumados a associar criminalidade e loucura a desvios da mestiçagem, efeitos degenerados da hereditariedade.

Como mostra Maria Alice Rezende de Carvalho, numa época em que as principais cidades brasileiras passavam a anunciar novos repertórios acerca da vida em sociedade, e no momento em que a "imaginação rendeu-se ao imperativo do progresso e da integração do Brasil a um Ocidente transformado pelo fenômeno do industrialismo e pela emergência das sociedades de massa", expressam-se movimentos opostos, repletos de "deslumbramento", mas também de "pavor". Deslumbramento diante das novas benesses das cidades, pavor frente ao desmoronamento da ordem reconhecida, ou em face das novas formas de segregação. Nas novas urbes, mais do que as quimeras fáceis do progresso único e obrigatório, impunha-se agora um arranjo incômodo entre o passado e o futuro, o novo e o velho, "o mundo do asfalto e os bolsões da miséria"4. Diferente da suposta marcha evolutiva, única e mandatória, ocorre uma sobreposição de temporalidades, e a afirmação de uma modernidade periférica e, assim, problemática. Diante de um republicanismo radical, que se manifesta nomeadamente na primeira década do século, de uma faxina social nas cidades e da evidência de novas formas de exclusão, eclodem várias revoltas e manifestações de cunho popular que de alguma maneira alardeiam e denunciam as falácias desse processo que prometia a "civilização".

Dessa forma, por aqui, o conceito de modernização combinou-se com o de tradição. Se de um lado os engenheiros convertiam-se em símbolos máximos da modernidade, de outro, práticas rituais legadas dos tempos da escravidão insistiam em dividir os mesmos espaços dessa urbanidade recém-inaugurada. Talvez por isso o movimento foi, ao mesmo tempo, de acomodação e de transformação das grandes capitais nacionais, traduzidas como cartões postais brilhantes dessa nova era anunciada pela iluminação a gás, pela fotografia que prometia o milagre de driblar a temporalidade e fixar o que arriscava se mover, ou das invenções, que

4. REZENDE DE CARVALHO, Maria Alice. Quatro vezes cidade. Rio de Janeiro: Sette Letras, 1994, p. 16-17, 27. 
inspiradas pelo "milagre tecnológico" do avião e de Santos Dummont que ganhou os ares, prometiam de tudo: casas móveis, apartamentos flutuantes, chuveiros portáteis, sapatos velozes, e assim por diante.

Além de Santos Dumont, Oswaldo Cruz dividia o pódio das personalidades que haviam desafiado os "entraves do passado". Com sua campanha de sanitarização, o cientista havia provado que era possível erradicar epidemias, mas, não por coincidência, havia inflamado a ira popular, expressa na Revolta da Vacina de 1904. Progresso e tradição eram, pois, lados não de duas, mas da mesma moeda. O fato é que havia algo de incômodo e de difícil tradução nesse novo aglomerado ético que agora reunia urbanidade, progresso e industrialização. É fato que estava em curso um processo inédito, que implicava acelerada transformação do espaço urbano e sua eleição como novo locus das representações, a despeito dessa modernização não alcançar de modo homogêneo todo o país. No entanto, e na mesma medida, uma série de intelectuais anotavam tais mudanças com grande desconfiança e ceticismo, aliando-se ao lado dos excluídos.

O dissenso surgiria expresso nos ensaios dos intelectuais nacionais, mas estaria presente também nos jornais, na literatura que apontava para as novas estratificações urbanas e para a formação de grupos outrora integrados ou não evidentemente isolados: o gaúcho, os afro-brasileiros, os sertanejos, os seringueiros, os indígenas da floresta. A cidade surgia assim reformada - de forma física e moral -, mas ao mesmo tempo tornava-se mais corriqueiro questionar a existência de uma só via que levava à civilização. A urbe era agora palco do conflito, personificado pelas assim chamadas "camadas perigosas", as hordas, o movimento de reação "dos de baixo".

O importante é que, no final do século XIX, e a partir de tantas novidades oferecidas por esse momento de mudanças velozes, reordenava-se a velha tópica do Paraíso terreal, da Terra sem males, dos Trópicos plácidos, ideário que inundou a imaginação local e o olhar estrangeiro durante tanto tempo. Um país de muitas raças convivendo em situação de conflito social, moral e político, uma nação dividida por tantas diferenças regionais e raciais, eis aí o novo regime de dualidades que se enraizavam até mesmo nos discursos de época. Por uma parte, a cidade surgia como uma nova modalidade de ambiência, definida pela indústria, pelas oportunidades de trabalho, pelo mercado, mas também por uma política de exclusão e de distanciamento de toda sorte. Por outra, os "demais Brasis", perdidos nos sertões, longínquos na realidade e na imaginação, ou nas florestas fechadas. Aí estavam dois Brasis que eram na verdade um só, mas a conviver de maneira ambivalente e conflituosa. Se nossos modernistas 
paulistanos elegeram na antropofagia um símbolo de evidente "fertilidade cultural", coerente com um certo "espírito e sentimento de época", também é claro como vários pensadores tomaram a diferença não como fermento, mas tal qual veneno a minar nossas possibilidades de entrar e conviver com a modernidade.

Além do mais, largas parcelas dessa sociedade, definitivamente mestiçada, experimentavam nesse momento um processo de queda social, uma espécie de "intimidação social", diante da realidade que se abria, pós escravidão. Muitas famílias que há muito tinham se separado das amarras do cativeiro, viram-se, por motivos econômicos, sociais e raciais, presas a um processo de rebaixamento. Indivíduos que receberam educação destacada em finais do século XIX e que se distinguiram por sua erudição e especialização, viram suas pretensões ruírem, sendo percebidos e plasmados a essa nova massa que agora ganhava a cidadania e a condição de libertos. Esse verdadeiro perigo de confusão social a que se viam expostas famílias cada vez mais remediadas, e sofrendo um processo de achatamento social que as convertia em classes médias destituídas e moradoras dos arredores e subúrbios das cidades, convertia-se rapidamente em princípio de realidade. Muitos não admitiam ver-se confundidos e misturados com negros e mulatos recém-saídos da escravidão. Outros constituíam novos laços de solidariedade e negavam-se a serem associados à imagem de libertos: termo forte, que reacendia a imagem da escravidão, a qual, pretensamente longe e terminada, insistia em se reapresentar ao menos como temor e apreensão. Na verdade, a abolição "aboliu" todo um complexo sistema de mecanismos sociais de distinção, tão próprios e necessários em uma sociedade de tipo estamental, ou cuja diferenciação se dava por nascimento. Durante o Império, e pela própria natureza do regime escravocrata, previa-se a mobilidade e no limite a alforria, com o detalhe de que essa se dirigia exclusivamente ao indivíduo. Significa dizer que a escravidão possibilitava por vezes a mobilidade individual, mas não a social em maior escala.

Estamos nos referindo justamente a um grupo que parece numeroso e que, nos termos de Maria Sylvia de Carvalho Franco, representava os "homens livres da sociedade escravocrata", ou uma nova "classe média" numa sociedade estamental, sem classes e muito afeita a proteções e jogos de favores. Ora, com a República e com a entrada em vigor de uma ordem social em mudança, e que passa a classificar os cidadãos a partir de critérios raciais, a instabilidade da posição desses grupos torna-se evidente, e, ademais, ameaçadora. Afinal, antigos privilégios e distinções mais próprios do Antigo Regime são transformados em tabula 
rasa nesse mundo de cidadãos desempatados por critérios afeitos ao determinismo biológico, entre outros.

Por outro lado, não era menor o medo da reescravização ou de novos trabalhos compulsórios, pois a insegurança da própria República gerava temor e saudades da monarquia. Não de uma monarquia exatamente encontrada na realidade, mas daquela que, agora, vista ao longe, lembrava segurança e calma, e era prontamente transformada em mítica. Por aí se explicam projeções e imaginários que atribuíram à Princesa Isabel, nominalmente, o final do regime escravocrata e o beneplácito da abolição. Se parte da população entendeu a abolição como um processo revolucionário, palco para a projeção de diferentes modelos a desenhar um futuro mais democrático e inclusivo, no país ela foi igualmente percebida como "dádiva", benesse, e não como o resultado de luta e conflito. Nada como lembrar das máximas do antropólogo Marcel Mauss, que lidando certamente com outro contexto, em seu "Ensaio sobre a dádiva", mostrou como faz parte do dom a ideia de retribuição. Chamar a atenção nesse sentido significa destacar o individualismo (e não o classismo) com que foi absorvida a abolição. Individualismo conectado ao personalismo brasileiro, quando então faz todo o sentido a ideia maussiana da reciprocidade entre a grande pessoa (no caso da Princesa Isabel) e a classe dos escravos. Quer dizer, o Estado não aparece aí como expressão da sociedade civil, mas sim como expressão da grande pessoa. Modo realmente curioso de relação: o Estado é tornado pessoa (Pedro II, Isabel e depois Vargas) para fazer frente a classes ou grupos da sociedade, numa dialética - para ficarmos nos termos de Roberto Da Matta entre indivíduo e pessoa no Brasil. Isto é, aquele que recebe um presente, sente-se coercitivamente compelido a retribuí-lo, isso quando não se estabelecem graus de gratidão e de subserviência. Ora, realizada a abolição, boa parte da população negra, recém-liberta, atribuiu à monarquia e à Regente o mérito da "glória concedida". É nessa perspectiva que se entendem movimentos como a Guarda Negra (grande defensora da realeza contra as manifestações republicanas), assim como as inúmeras demonstrações de simpatia e de afinidade para com o Regime Monárquico. Na medida em que a libertação não foi assumida como um ato político e devedor da própria organização do grupo escravo, o corolário foi admitir fidelidade para aqueles considerados como "os donos do ato". Criava-se assim uma monarquia sagrada, um rei e uma princesa imaginários - muito longe do sistema destituído -, distantes do aspecto "terreno" dos nossos primeiros representantes republicanos, destituídos de carisma ou aceitação popular. 
Portanto, são ambivalentes as compreensões e recepções da República, sobretudo em seus primeiros anos. O processo mostra-se assim cheio de recuos, avanços, muitos entraves e ambiguidades. Afinal, a tradição se inscrevia em meio à modernidade, e o novo se confundia com o velho. E é junto a esse caldo de paradoxos e conflitos que se desenha nossa "Semana de Arte Moderna" - um sopro de vanguarda, de cosmopolitismo e certo otimismo, nesse contexto - mas também outras experiências sociais de caráter mais político reivindicativo.

Nesse sentido, ouso expor um pouco mais a experiência de Lima Barreto. Não para dela fazer um exemplo que ilumina toda uma época, ou muito menos "para estragar a festa" do ano de 1922. Ao contrário, ela representa um "outro caso", uma outra face de nossa modernidade. Quem sabe ela sirva como testemunho do ambiente que assolou parte da intelectualidade brasileira de inícios do século $X X$, cada vez mais descrente dos destinos dessa nação, entregue primeiro aos militares e depois a presidentes civis, obrigados a vincular-se ao comércio agroexportador, em especial do café.

Por isso talvez possamos entender Lima Barreto não como "testemunho", no sentido de só dizer "verdades" sobre seu contexto, mas antes como "um termômetro em temperatura elevada". Ele denunciou como poucos as falácias da modernidade, a violência das práticas policiais, os costumes importados, as modas fúteis e os processos acelerados de exclusão social. Funcionário público, atuava como amanuense, uma espécie de escriturário, na Secretaria da Guerra, depois de amargar um fracasso na escola superior Politécnica e sucessivas tentativas falhadas de se inserir no reluzente “clube da literatura”, que nessa época passava as tardes nas confeitarias da antiga Corte e se reunia na recém-fundada Academia Brasileira de Artes. Arrimo de família, depois que a loucura de seu pai o tirou do trabalho, Lima Barreto escrevia quando e como podia. Não poucas vezes, usava seu tempo ocioso de funcionário público (emprego que tanto criticava) e o próprio papel timbrado da Secretaria, para não deixar passar, ou esquecer, trechos de romances que lhe vinham à cabeça, ensaios acerca da situação da cidade ou textos de memória e nitidamente autobiográficos.

Como as folhas deveriam ser poucas e a imaginação muita, Lima escrevia no verso e no reverso dos papéis, ou recortava-os em tiras. Foi exatamente isso que aconteceu no caso do conto "O traidor". Na folha de frente, o escritor terminou seu conto e destilou toda sua conhecida verve contra o Teatro Municipal do Rio de Janeiro, naquela altura, recém inaugurado: 
O Teatro Municipal é inviável. A razão é simples. É muito grande e luxuoso (...). Armaram um teatro cheio de mármores, de complicações francesas, um teatro que exige casaca, altas toiletes, e quem com ele levantar a arte dramática, apelando para o povo do Rio de Janeiro. Não se tratava bem de povo que sempre entra nessas coisas como Pilatos no Credo. Eternamente ele viveu longe desses; não tem mesmo notícia deles, e, se o tem, despreza-os totalmente.

Já no outro lado do papel, fez uma série de elucubrações acerca da sua vida e suas lembranças de infância, logo após a abolição da escravidão:

Era bom saber se a alegria que trouxe à cidade a lei da abolição, foi geral pelo país. Havia de ser, por que já tinha entrado na convivência de todos a sua injustiça originária. Quando eu fui para o colégio, um colégio público, à rua do Rezende, a alegria entre a criançada era grande. Nós não sabíamos o alcance da lei, mas a alegria ambiente nos tinha tomado. A professora, D. Tereza Pimentel do Amaral, uma senhora muito inteligente, creio que nos explicou a significação da coisa; mas com aquele feitio mental de crianças, só uma coisa me ficou: livre! livre! Julgava que podíamos fazer tudo que quiséssemos; que dali em diante não havia mais limitação aos progressistas da nossa fantasia. Mas como estamos ainda longe disso! Como ainda nos enleiamos nas teias dos preceitos, das regras e das leis! (...) São boas essas recordações; elas tem um perfume de saudade e fazem com que sintamos a eternidade do tempo. $\mathrm{O}$ tempo inflexível, o tempo que, como o moço é irmão da Morte, vai matando aspirações, tirando perempções, trazendo desalento, e só nos deixa na alma essa saudade do passado, às vezes composto de fúteis acontecimentos, mas que é bom sempre relembrar. Quanta ambição ele não mata. Primeiro são os sonhos de posição, os meus saudosos; ele corre e, aos poucos, a gente vai descendo de Ministro a amanuense; depois são os de Amor - oh! como se desce nestes! ... Viagens, obras, satisfações, glórias, tudo se esvai, e esbate com ele. A gente julga que vai sair Shakespeare e sai Mal das Vinhas; mas tenazmente ficamos a viver esperando, esperando... O que? O imprevisto, o que pode acontecer amanhã ou depois; quem sabe se a sorte grande, ou um tesouro descoberto no quintal? ${ }^{5}$

5 BARRETO, Lima. Manuscrito. Rio de Janeiro, Fundação Biblioteca Nacional. 
Dizem que quem conta um conto aumenta um ponto. Afinal, como toda história guarda um processo, essa continua pelo Estado Novo adentro, o qual, de alguma maneira, deu feição e forma ao processo de institucionalização que então se iniciou, assim como às diferentes formas de cidadania e de experimentação do modernismo. Por outro lado, são hoje conhecidos os assédios dos modernistas paulistas a Lima Barreto, a quem consideravam uma voz divergente em relação ao domínio dos Acadêmicos e da Academia. Sua postura boêmia, a defesa da oralidade, a crítica ao lado assentado da literatura carioca, faziam dele uma referência à altura para os jovens modernistas de São Paulo. Mas temos no Rio de Janeiro, e em particular no ambiente do subúrbio carioca, vivenciado por Lima Barreto, uma outra modernidade.

Voltemos, ainda uma vez, ao belo texto de Lima Barreto, que guarda um tom cético e melancólico tão próprio dessa geração que acreditou demais na loteria de "um novo tempo". Ele parece revelador de um ambiente que excede seu autor, sua posição social e perspectiva particular. É possível dizer, sem medo de errar, que ser mestiço ou negro significava, nesse momento, um obstáculo forte a cercear a utopia republicana da igualdade e da cidadania, e, ainda mais, de autonomia intelectual, ou mesmo do projeto sem "pejas ou amarras" que parecia se anunciar com o modernismo. Um novo tempo, uma volta ao Brasil real - mulato -, um diálogo com as vanguardas... Aí estavam alguns dos não poucos projetos desse novo Brasil, que pouco se parecia com a alcunha de uma República Velha. Lima Barreto denuncia o escravismo arraigado, é verdade, mas só pode fazer isso (sem maiores consequências) por pelo menos duas razões importantes: uma, que o ambiente republicanista já o permitia, e outra, que ele próprio já se afigurava como uma grande figura (de novo, a importância das grandes figuras no Brasil), assim assentando sua legitimidade, e coragem também, na pessoa (devidamente enredada), e não no indivíduo (visto como sem rebanho ou fora de redes capazes de projetar o locutor e fornecer a este uma caixa de ressonância). Dessa maneira se projeta a ambivalência do autor, assim como a decadência (física, psíquica, social) que Lima Barreto enfrentaria na vida: ele então passaria de pessoa distinta para indivíduo indistinto, nivelado pela raça e pela alienação no hospício.

\section{Lima no hospício}

Assim como história nunca foi conta de "dois mais dois são quatro", nessa trajetória de Lima Barreto nada seria previsível. Se a experiência 
da qual todos nós somos de alguma maneira herdeiros nos fez ver o Brasil sob nova chave, "a partir de sua abertura para a modernidade", gostaria de fazer aqui o papel de "advogado do diabo". Perguntar por projetos que "não foram" e não ocorreram. Um pouco antes da Semana de 22 morria Lima Barreto, ele que, depois de várias internações, havia desistido de sua carreira de escritor e de ser uma voz crítica em relação a seu contexto e aos cientificismos que por aqui grassavam.

O caso é particularmente interessante, uma vez que Lima Barreto, longe de ser "vítima de seu tempo", foi, sobretudo nos primeiros momentos da República, um grande protagonismo. Atuou de maneira efetiva em diversos eventos que marcaram o período - como a Revolta da Vacina, ou no julgamento de militares que, favoráveis a Hermes da Fonseca, assassinaram alguns estudantes que se manifestavam contra o governo - assim como agenciou seu lugar de persona literária na contramão do "mandarinato" dos acadêmicos da ABL. O escritor teve seu jornal próprio - o Floreal -, liderou um grupo (boêmio), assim como publicava artigos, crônicas, folhetins e pequenos contos nos grandes jornais cariocas. No entanto, também não é o caso, igualmente, de conferir a ele um protagonismo isolado, imune às vicissitudes e constrições de seu tempo ou deixar de lado a carga de sofrimento que marcou os anos finais de sua vida. Na verdade, todo indivíduo encontra-se enredado nas teias que ajudou a tecer e, pensado nesses termos, Lima Barreto é mesmo um personagem de seu tempo ${ }^{6}$, um tempo carregado de todo tipo de polêmica e controvérsia.

Nada era certo, e por isso vivia-se um ambiente de ambiguidade e insegurança. É por isso que o contexto pedia reação, protagonismo e também agência. Cor no Brasil sempre foi um marcador social da diferença dos mais operantes, a despeito de carregar certa fluidez e indeterminação, uma vez que se pauta em critérios circunstanciais, econômicos ou sociais. Nesse sentido, ora tornar-se mais branco, ora reafirmar a cor e a própria raça eram medidas urgentes nesse momento que demandava manipulações variadas. Os Rebouças diluíram, de alguma maneira, sua cor até "trocarem de pele", quando no exterior foram obrigados a se enxergarem como negros ${ }^{7}$; Edson Carneiro virou especialista em temas negros e, durante os anos de formação, perto da Academia dos Rebeldes, entendia-se como branco, já que a cultura o emancipava ${ }^{8}$. Já

6 Cf. GEERTZ, Clifford. A interpretação das culturas. Rio de Janeiro: Zahar, 1987. Geertz, por sua vez, cita Weber nesse trecho.

7 REZENDE DE CARVALHO, Maria Alice. op. cit.

8 Sobre Edson Carneiro, vide ROSSI, Gustavo. O intelectual feiticeiro: Édison Carneiro e o campo de estudos das relações raciais no Brasil. Tese de Doutorado em 
Lima Barreto agenciou sua cor, mas de forma ambivalente. De um lado, acentuou sua origem negra e escrava sempre que pode: chamou sua casa de "Vila quilombo" e dizia estar escrevendo um Germinal Negro e uma História da escravidão $0^{9}$. Como literato explorou a cor de seus personagens, ou mostrou o preconceito vigente nessa sociedade, como em Clara dos Anjos (que tem como protagonista uma jovem mulher negra que acabou "perdendo-se" na vida), ou em Recordações de Isaías Caminha cujo personagem "percebeu que era negro" a caminho da cidade. De outro lado, porém, sempre que pôde, Lima mostrou sua diferença para com os demais habitantes negros do subúrbio - lugar de sua morada e inspiração -, assim como denunciou a barbárie e falta de cultura dessas populações. "Essa estranha gente do subúrbio", dizia ele, ou melhor, seu alter ego e narrador onipresente em Clara dos Anjos. Se Lima Barreto desfez da métrica do modelo oficial, se defendeu uma literatura mais próxima da fala das ruas, não poucas vezes interrompe seu relato para ironizar a linguagem "errada do povo", eivada de termos herdados do passado escravocrata. Talvez essa "multivalência" que Lima Barreto sentiu na pele explique não exatamente uma contradição ou um recuo do autor negro-mestiço em relação à massa popular dos negros e mestiços, mas sim sua consciência, talvez nem tão clara para o próprio Lima Barreto, de que a promoção social de negros e mestiços no Brasil dependia da agregação de variáveis positivas, como pela educação civil. Então, esse esforço do cultivo do espírito poderia apagar, diminuir ou refazer o que aparecia como marcador dado (a naturalização cientificista das raças). Quer dizer, Lima Barreto estaria contrapondo, para a finalidade das transformações sociais, o inato ao adquirido, o biológico ao social, o dentro e o fora, o dado ao construído (ou, nos termos de hoje, a genética/hereditariedade ao epigenético/ambiental).

O fato é que Lima Barreto buscou manter sua "diferença”, em tudo distinta dos demais "libertos" nivelados pelo corpo da lei. Em Clara dos Anjos, por exemplo, assim descreve o subúrbio: "a residência dos pais de Cassi ficava num subúrbio tido como elegante, porque lá também há estas distinções. Certas estações são assim consideradas e certas partes de determinadas estações gozam, às vezes, dessa consideração (...) Nos subúrbios há disso (...) Essa estranha gente" ${ }^{10}$. E diz mais, revelando

Antropologia Social. Campinas, Unicamp, 2011; e sobre o autor, ver AUCUNA, Maurício. "Entre rodas de capoeira e círculos intelectuais: disputas pelo significado da capoeira no Brasil (1930-1960). São Paulo: Alameda, (no prelo).

9 Vide Diários de Lima Barreto.

10 BARRETO, Lima. Clara dos Anjos. In: Contos completos. SCHWARCZ, Lilia Moritz (org.). São Paulo: Companhia das Letras, 2010, p. 110. 
uma exterioridade, pouco experimentada no dia a dia: "Uma diferença acidental de cor é causa para que se possa julgar superior à vizinha; o fato do marido desta ganhar mais do que o daquela é outro"11.

Mas não há situação em que essa condição ambígua - que inclui um movimento de se afirmar e de distinguir - tenha se pronunciado de maneira mais aguda do que nas duas internações no Manicômio Nacional, em 1914 e 1919. Taussyg chama de mímeses essa perspectiva própria da literatura capaz de registrar: "sameness and difference, of being like, and of beeing other"12. Trata-se assim de pensar nesse espaço "entre". Proximidade e distância, contato e alteridade são, pois, modalidades presentes nessas narrativas "entre", assim como o tema da loucura. Nesse caso, também, a literatura não resulta na mera coincidência de termos numa unidade do "eu", mas sim numa espécie de jogo espelhar, que identifica, mas também causa repugnância. O hospício funciona como metáfora do grupo, mas também como realidade última para esse escritor, que chegou a desabafar nas páginas de seu diário, que seu próprio corpo o traía. Crítico sagaz das teorias raciais, Lima Barreto, porém, temeu que “os estigmas deterministas" que tanto combatia estivessem, por linhas tortas, escrevendo a mesma história nas páginas do seu destino. O medo da loucura, expressa no espelho e no espelhamento, foi tema de uma série de contos e narrativas, entre elas aquela de título homônimo e escrita por Machado de Assis. Mas nesse caso, ser louco é virar e assumir o outro espelhado. E não por acaso a experiência moderna associou historicamente a faculdade mimética com o primitivo, com a criança ou com o louco.

E pensemos na situação de Lima Barreto, convertido em louco e lutando por garantir sua persona (frente aos demais literatos, mas também diante de seus vizinhos no subúrbio "que é negro") a partir de 1914, justamente num local de mímesis, em que a ameaça diante da fixidez das identidades e diferenças está sempre presente. Diferente da "cidade letrada"13, que racionaliza espaços sociais, identifica desviantes, raças e classes para tornar tudo pacífico, ordenado e classificado, o espaço da mímeses é justamente aquele que borra fronteiras. Nesse espaço, ficam ainda mais claras as negociações e ambiguidades estabelecidas no encontro mimético entre o eu e o outro. Dessa maneira, se com sua literatura realista e engajada (segundo sua própria definição) Lima Barreto

11 Idem, p. 111.

12 TAUSSYG, M. Mimesis and alterity. A particular history of the senses. New York: Routledge, 1993, p. 129. Vide SÁ-CARVALHO, Carolina. "O aspecto do outro e o mesmo", Princeton/ mímeo, onde a autora faz uma excelente discussão sobre a literatura abolicionista em Cuba.

13 RAMA, Angel. La Ciudad letrada. Buenos Aires: Ediciones del Norte, 2002. 
procura tornar o "outro social" numa espécie de "nós nacional" - se não na perspectiva da inclusão, pelo menos da grande exclusão social - nos relatos e em sua novela produzida durante sua estada no Hospício Nacional - Cemitério dos vivos - o processo de espelhamento é quase literal. O escritor mistura o nome do personagem com o seu próprio, mescla episódios reais com outros imaginados, e expõe seu "eu", sem tantas mediações. Por lá é que conclui que "a lei não era para todos" e se inclui na mesma legenda dos demais: “o destino me nivelara. Esqueci-me de minha instrução, da minha educação, para não demonstrar com uma inútil insubordinação(...) Não reclamei, não reclamo, não reclamarei; conto unicamente"14.

\section{O homem da ficha antropométrica e do uniforme Pandemônio}

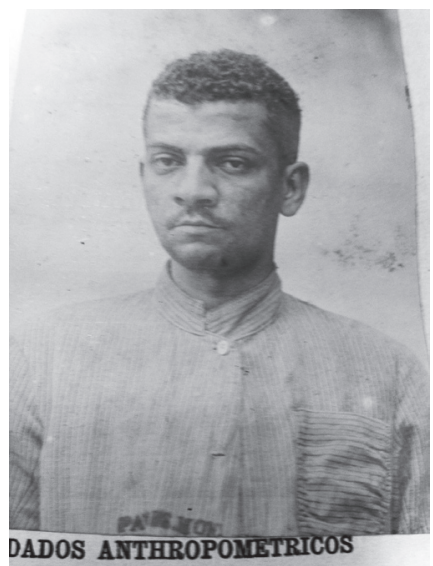

Nome: Affonso Henriques de Lima Barreto

Idade: 33

Cor: branco

Estado civil: solteiro

Nacionalidade: brasileira

Profissão: empregado público

Entrada: 18-08-14

Diagnóstico: alcoolismo

Tratamento: purgativo, ópio

Retrato em branco e negro, ficha antropométrica preenchida... é dessa maneira que Lima Barreto aparece nos registros do Hospício Nacional de Alienados do ano de 1914. A instituição remonta ao ano de 1841, com o nome de Hospital Pedro II, quando José Clemente Pereira, provedor da Santa Casa de Misericórdia do Rio de Janeiro, iniciou campanha pública em favor da criação de um hospício de alienados na corte. Era preciso separar os loucos dos demais doentes, assim como ministrar-lhes tratamento diverso, em função da natureza agora reconhecida da moléstia. Mas essa estrada seria pavimentada nessa via crucis da loucura, até chegarmos aos anos 1914.

14. BARRETO, Lima. Diário do hospício e O cemitério dos vivos. MASSI, Augusto e MOURA, Murilo Marcondes de (orgs.). São Paulo: Cosac Naify, 2010, p. 183-184. 
Temas como loucura andavam em voga, e, sobretudo num país mestiçado, não eram poucos os teóricos que defendiam teses sobre a maior incidência de casos numa nação de raças em desequilíbrio, e o manicômio parecia ser seu grande laboratório ${ }^{15}$. Em primeiro lugar, a organização da construção separava os homens (que ficavam na ala esquerda) das mulheres (na direita). Além do mais, os alienados eram divididos a partir de sua origem social: aqueles admitidos gratuitamente (indigentes, escravos e marinheiros) e os pensionistas (discriminados como "primeira classe" e com tratamento especial, e "segunda classe", com direito a quarto para dois internos). Os alienados eram ainda diferenciados pelo comportamento: tranquilos, agitados, imundos, afetados por moléstias acidentais ou crônicas. Bastante simples, a classificação combinava critérios que atentavam para a condição social, a higiene, a incidência de outras moléstias, a manifestação da loucura e seu grau de periculosidade.

É bom destacar que, com a chegada da República, não apenas o regime iria mudar, como se procedeu a uma alteração acelerada de nomes, títulos e emblemas. E o "Pedro II" não ficaria atrás: logo em janeiro de 1890 seria rebatizado como Hospício Nacional de Alienados e, em 1911, Hospital Nacional de Alienados. Por outro lado, nesse contexto, novos modelos entravam em voga, sobretudo a "teoria da degenerescência" elaborada por Morel e difundida por Magna, e a do "organicismo", que estabelecia a predominância dos elementos biológicos aos sociais. Eles levariam a uma mudança de enfoque com relação à loucura e à importância das determinações hereditárias. A essas conclusões recentes correspondiam novas terapêuticas, uma medicalização crescente e um aprimoramento desse tipo de instituição asilar.

É esse tipo de estabelecimento que recebe Lima Barreto, em agosto de 1914. Ele, já escritor de certa fama, parecia, diante dessa situação, como mais uma personagem anônima qualquer, um alienado passageiro já que sujeito ao delírio do álcool. Sua história pessoal parecia repetir o que as teorias raciais da época, e os prognósticos mais negativos e deterministas, apontavam: não se escapava da raça da origem e dos seus estigmas. Afinal, segundo as teorias da degeneração, indivíduos miscigenados carregariam "vícios" das duas raças que as formavam. Estabelecia-se uma correlação clara entre raça e doença mental, e se

15 Pioneira nesse sentido é a escola tropical baiana, liderada por Nina Rodrigues, que advogava exatamente esse tipo de modelo. Para uma leitura mais aprofundada vide, entre outros, CORREA, Mariza. A ilusão da liberdade. Campinas: Unicamp, 2002; e também meu livro $O$ espetáculo das raças. São Paulo: Companhia das Letras, 1998 . 
a loucura não tinha uma única raça, negros e mestiços estavam mais predispostos a ela, na medida em que eram entendidos como intelectualmente inferiores. Henrique Roxo, médico do Hospital, em pronunciamento no Segundo Congresso Médico Latino Americano (1904), asseverava que negros e pardos deveriam ser considerados “tipos” que não evoluíram; seriam retardatários entre nós. Segundo ele, se cada um carrega uma “tara hereditária”, no caso desses grupos ela era "pesadíssima”. O médico não deixava de incluir argumentos sociais, culpando a abolição "repentina”, assim como o crescimento das cidades pelos males que afligiam o país. Por isso, eles teriam maior propensão para a vadiagem, o álcool e demais distúrbios mentais.

Lima Barreto conhecia a loucura de perto; convivera com ela desde muito jovem. Seu pai, João Henriques, seria um dos primeiros desempregados da monarquia; e para sobreviver aceitaria, em março de 1890, trabalho mal remunerado como almoxarife nas Colônias de Alienados da Ilha do Governador. Conheceu também a própria loucura do pai que, a partir de 1902, mostrou os primeiros sinais e nunca mais voltou à razão. Isso fez com que Lima, filho mais velho, virasse arrimo de família, assim como que, vexado, convivesse com os urros diários do pai na casa no subúrbio carioca em que passariam a viver ${ }^{16}$.

O escritor foi internado a primeira vez em 1914 e teve seus dados anotados nos prontuários de "observação clínica” do Hospital Nacional de Alienados. Na mesma época e ano, aparecem outros rostos de "observados", hoje meros desconhecidos, cada um carregando seus dramas pessoais, descritos nos pequenos relatos que mencionam brigas, manias religiosas ou políticas, agressividade, criminalidade, fanatismo religioso, alcoolismo, ciúmes e toda uma vasta gama de experiências, todas classificadas por um rótulo forte e generalizante. A loucura parece ser o contrário da ordem e da normalidade, uma corruptela para pensar em exagero, afetação, agitação, periculosidade, ou, como mostra Castel, "um excesso que é falta" ${ }^{17}$.

16 Há uma coincidência importante a anotar. No começo de 1902 houve um escândalo noticiado pelos jornais, quando o almoxarife do HNA, Oscar Adolpho da Costa Braga, transformou-se no centro das denúncias sobre a precariedade de funcionamento das instituições cariocas. O Jornal do Commercio de zo de janeiro de 1902 mencionava o convívio entre crianças e adultos. A Gazeta de Commercio acusava algumas irregularidades no uso da verba pública. Sabe-se João Henriques deu os primeiros sinais de loucura por causa de umas contas que não fechavam. Resta saber se teve acesso a essas notícias.

17 CASTEL, Robert. A ordem psiquiátrica. A idade de ouro do alienismo. Rio de Janeiro: Graal, 1978, p. 111. 
O conjunto das fichas traz um universo de certa maneira recorrente: boa parte dos internados são brasileiros, sendo os estrangeiros em geral portugueses e espanhóis. Divididos por cor - brancos, pardos ou negros -, a maioria deles são classificados como brancos, a despeito de as fotos traírem a objetividade das fichas, uma vez que a pele, os traços, os cabelos revelam que a maioria dos casos incide sobre uma população escura e pobre. Também se anotou, quando possível, ou quando o silêncio do paciente não escorre para as próprias fichas, a profissão do novo interno. As mulheres foram em sua totalidade definidas como "domésticas"; já os homens em sua maior parte como "trabalhadores", depois comerciantes e ainda estivadores, mecânicos, tipógrafos, pedreiros, alfaiates, serralheiros, carregadores, um "chauffeur" e dois empregados públicos; dentre eles Lima Barreto. Aí estava o que restava da identidade desses cidadãos temporariamente destituídos de seu direito de arbítrio.

Nas fichas de observação, a partir de pequenos detalhes, percebe-se o diálogo difícil e por certo hierarquizado entre doente e o médico, no sentido de garantir, de um lado, a singularidade e, de outro, deixar-se catalogar a partir de uma situação que, contra a vontade de muitos, parecia unir a todos. Ou seja, se o "diagnóstico" continha certa variação - alcoolismo, epilepsia, psicose periódica, paralisia geral, delírio episódico, demência senil, debilidade mental, esclerose cerebral, sífilis cerebral ou simplesmente psicose dos degenerados; isso quando os termos não vinham seguidos por um ponto de interrogação. Já o tratamento era bastante recorrente, resumindo-se à prescrição de purgatório, ópio ou tônicos calmantes. Por outro lado, enquanto o notário parece tentar preencher a profissão sempre de maneira pouco específica pode-se notar, em alguns casos, o esforço do interno de discriminar a profissão e, assim, ganhar um local diferenciado nessa instituição que tende a jogar a todos na mesma grande vala comum da loucura. Lima Barreto queria ser classificado como escritor; ficou apenas (mas pelo menos) como funcionário público. Profissão que tantas vezes ironizou e que, durante toda a vida, considerou menos relevante do que o seu compromisso com a literatura.

Lima Barreto, sempre se espelhando em Dostoievsky, seu autor predileto, em seus diários anota a "humilhação" que sentiu ao perder sua identidade e se ver transformado num "mulato", desses que tantas vezes manifestavam a fraqueza da loucura mestiça - a "psicose dos degenerados". Pouco adiantaria, nessa hora, seu conhecimento crítico do darwinismo racial ou suas críticas nesse sentido: "A capacidade mental 
dos negros é discutida a priori a dos brancos a posteriori. A ciência é um preconceito grego, é ideologia"18.

\section{Anamnese, pavilhão de observação como metáfora}

O Livro de Observações do ano de 1914 continua intacto, apenas manchado pelo tempo. Traz questionários com conteúdo padrão, respondidos ou em parte vazios, fotos em branco e preto, seguidas de outras descrições. A impressão causa impacto, tal a intimidade lá revelada, de personagens cujos nomes e feições parecem ter se perdido na pátina do tempo. Mas um deles, cuja entrada se deu no dia 18 de agosto, com certeza se destaca em meio a essa massa de desconhecidos: O escritor Affonso Henriques de Lima Barreto, que tinha então 33 anos. A foto chama atenção, igualmente, por conta do estranhamento da situação e da imagem que lá surge estampada. Portando roupas de detento, com um carimbo estampado em sua roupa - Pandemônio -, o rapaz mira a câmara fotográfica, e se não fosse um certo olhar entristecido, um pouco baixo, pareceria desafiá-la. Pandemônio tem origem inglesa pandemonium, através do radical grego pân, que significa "todo", sendo acrescido o termo grego daímon, que quer dizer "demônio". Tal neologismo foi criado pelo poeta inglês John Milton (1608-1674), no seu Paradise lost, para designar o palácio de Satã. É também o designativo para a capital imaginária do Inferno, significando o mesmo que tumulto, balbúrdia, confusão. O que importa é que a imagem, acrescida do seu título, é motivo de espécie. Ainda mais porque em seu livro Cemitério dos vivos, que restou inacabado, Lima desenhara imagem semelhante do hospício: o inferno ou o cemitério.

O fato é que Lima andara bebendo, e muito, e sua expressão talvez seja devedora de seu estado, tal como descreve em seu Diário neste ano. De toda maneira, e diferente de outros internos, não esconde o rosto ou vira-o de lado, evitando o olhar; nem ao menos usa de qualquer subterfúgio, como tapar o rosto com as mãos, ou com outro objeto. No seu prontuário, além da discriminação da profissão, causa estranheza a "cor". Na ficha, contrariando o que a imagem evidencia, Lima Barreto é “branco". Já na fotografia, por detrás das olheiras profundas, do ar altivo, dos olhos desviantes, se destaca sua cor amorenada e o cabelo pixaim. O próprio Lima se preocupava em descrever com cuidado a cor de seus

18 BARRETO, Lima. Diários íntimos. um longo sonho de futuro. Diários, cartas, entrevistas e confissões dispersas. Rio de Janeiro: Graphia, 1998, p. 15 
personagens, chegando a detalhes impressionantes quanto às diferentes tonalidades que os distinguiam. Aí está essa maneira nacional de agenciar a cor, e hoje será difícil saber quem a atribuiu nesse momento: se o funcionário zeloso em "branquear" a todos, ou o próprio escritor, que em sua literatura sempre destacou o fato de ser negro. Nos Diários desabafou: "É triste não ser branco"19.

Vale a pena recorrer, também, à detalhada "inspeção geral”, constante do livro de "observações clínicas" ${ }^{20}$. Nela, estabelece-se novo diálogo entre Lima e o funcionário. Na primeira parte do laudo, o diagnóstico é claro e não permite prever qualquer debate: "O nosso observado é um indivíduo de boa estatura, de compleição forte, apresentando estigmas de degeneração física. Dentes maus; língua com acentuados tremores fribilares, assim como nas extremidades digitais". De imediato, chamam atenção duas palavras fortes no vocabulário da época: "estigmas de degeneração". Estigma é termo que vem da terminologia da antropologia criminal de Lombroso, que estudava as associações entre as raças mestiças com a criminalidade e a loucura. Estigma supõe a existência de traços fixos e essenciais, vinculados às raças, também entendidas como fenômenos naturais. Supõe ainda a ação da hereditariedade como fator determinante no comportamento populacional. Pior era, não obstante, a situação das "raças mistas", essas, sim, sujeitas a todo tipo de degeneração. Portanto, se Lima era branco na cor, poderia ser não tão branco no diagnóstico.

O procedimento seguia a orientação do hospital e também do professor Henrique Roxo, que em 1901 defendeu a tese "Duração dos atos psíquicos elementares nos alienados". Roxo substituiu seu orientador, Teixeira Brandão, na direção do Pavilhão de Observação do Hospital Nacional de Alienados e criou nova técnica para exame de "suspeitos de alienação". Segundo ele, o questionário não deveria ser fixo. O funcionário anotaria os dados físicos do paciente - sua estatura e aparência -, definiria a fisionomia e, por fim, seu estado geral (calmo, agitado, triste, alegre, concentrado, disperso) a partir da maneira como respondia às perguntas. Essa primeira fase seria fundamental para o estabelecimento de traços degenerativos. A próxima etapa era mais objetiva e visava os dados antropométricos (crânio, face, orelhas, nariz, olhos, cavidade bucal). Objetos de atenção eram também os órgãos genitais, o fígado, o

19 Idem, p. 85 .

20 BARBOSA, Francisco de Assis. A vida de Lima Barreto. Rio de Janeiro: José Olympio Editora, 2002. Francisco de Assis Barbosa reproduz tal documento na íntegra no Apêndice de sua famosa biografia sobre Lima Barreto. 
coração, o estômago e os intestinos. Por fim, vinha uma etapa considerada mais "subjetiva", pois visava aos dados anamnésticos, ou seja, as condições de vida do paciente. Nesse caso, Roxo recomendava ser necessário captar a simpatia do paciente e "deixá-lo falar"21.

Em suma, o objetivo era anotar cuidadosamente a fisionomia do paciente - considerada a janela do caráter. Anotavam-se também as tendências intelectuais e emotivas dos doentes, sendo o "excesso" sempre considerado sinal de loucura. Excesso religioso era logo definido como fanatismo, assim como pendores extremos pela política e, em especial, para o anarquismo eram igualmente estigmas fortes. Chamados de "loucos morais", anarquistas eram condenados por sua ideias e estigmatizados como doentes. O professor Álvaro Fernandes, da Faculdade de Medicina do Rio de Janeiro, mostrava, em 1898, como o anarquista era o tipo de louco moral por excelência "nascendo da luta social, da desarmonia entre o capital e o trabalho" 22 . Franco da Rocha, diretor do Juquery, defenderia em 1904 tese semelhante, estabelecendo correlações entre "loucura moral e radicalismo revolucionário". Pode-se imaginar o temor de Lima, assim como a insistência em calar sobre suas simpatias anarquistas, consideradas naquele local sinal de degenerescência. Esse é, portanto, e também, um diálogo de surdos, com o paciente buscando omitir dados de sua vida pregressa e o atendente buscando criar ambiente amistoso e que incitaria o interno "a falar".

Os inquéritos de entrada continuavam com os exames de "sensibilidade e motilidade", que no caso de Lima mostram-se "na íntegra". Já o exame de "reflexos" deixou a desejar, “com as pupilas reagindo só lentamente à luz". Esse deveria ser o efeito da bebida que castigava Lima havia alguns dias e que fizera com que fosse internado, delirando, depois de ter estado a vagar pelas ruas do centro do Rio. O álcool já acompanhava a vida de Lima Barreto havia bastante tempo. No diário do ano de 1910, ele menciona a sua "mania de suicídio" e a frequência do álcool: "Só o Álcool me dá prazer e me tenta... Oh! Meu Deus! Onde irei parar?" ${ }^{23}$. Nesse ano, Lima mostrava-se claramente deprimido, e em seu Diário, no dia 20 de abril de 1914, anotou: "O maior desalento me invade. Tenho sinistros pensamentos. Ponho-me a beber, paro. Voltam eles e também

21 Vide ENGEL, Magali G. Os delírios da razão. Rio de Janeiro: Editora Fiocruz, 20oı, p. 145 .

22 Vide texto de ENGEL, Magali G. As fronteiras da anormalidade: psiquiatria e controle social. História, Ciências, Saúde - Manguinhos, v. 3, nov. 1998-fev. 1999, p. $547-563$.

23 BARRETO, Lima. Diários íntimos. um longo sonho de futuro. Diários, cartas, entrevistas e confissões dispersas. op. cit., p. 63 . 
um tédio de minha vida doméstica, do meu viver cotidiano e bebo. Uma bebedeira puxa outra e lá vem a melancolia. Que círculo vicioso (...) O meu pai delira constantemente e o seu delírio tem a ironia dos loucos de Shakespeare" ${ }^{24}$.

Lima Barreto fora recolhido ao Hospício Nacional dos Alienados, em carro-forte, e por iniciativa de seu irmão Carlindo, que nesse momento trabalhava na polícia. O escritor, apesar de considerar que "andava atrapalhando a família", jamais perdoaria o irmão e a polícia. O conto "Como o homem chegou" ${ }^{25}$, que Lima incluiu na primeira edição de Triste fim de Policarpo Quaresma, é claramente inspirado no episódio. "A polícia da República, como toda a gente sabe, é paternal e compassiva no tratamento das pessoas humildes que dela necessitam; e sempre, quer se trate de humildes, quer de poderosos, a velha instituição cumpre religiosamente a lei. (...)". Os paralelos autobiográficos são evidentes: Fernando morava com o pai, nos arredores da cidade, assim como era acusado de bebedeira renitente ao lado de amigos vagabundos. Há um salto temporal no Diário, exatamente nesse momento, e é no dia 13 de julho que o escritor desabafa: “Enfim, a minha situação é absolutamente desesperada, mas não me mato (...). Hoje tive um pavor burro. Estarei indo para a loucura?"26.

Os casos de alcoolismo, como o de Lima, eram aqueles que restavam menos tempo recolhidos no hospital, e o escritor não fugiria à regra. Nessa primeira vez, ficaria internado apenas dois meses, que lhe custaram, porém, muito. Impressionantes são os dados anotados pelo escrevente M. Pinheiro: "Todos os aparelhos (digestivo, circulatório, respiratório) parecem normais"; o único que apresenta anomalia digna de nota é o genito-urinário que apresenta uma blenorragia", também conhecida na época como "esquentamento, purgação ou gonorreia”. A constatação da doença venérea representava novo sintoma de degenerescência, pois configurava "excesso" e falta de regramento, "perversão" diante de um modelo cujos limites de normalidade deveriam prever práticas sexuais circunscritas, prazer moderado e com finalidade reprodutora. Há aqui uma teoria dos humores operando, teoria esta que justamente assimilava boa saúde a equilíbrio, aos perigos, portanto, dos

24. Idem, p. 119.

25 Datado de 18 out. 1914. Foi publicado originalmente na 1. ed. de Triste fim de Policarpo Quaresma (Rio de Janeiro: Typ. Revista dos Tribunais, 1915, p. 333-352). Na Divisão de Manuscritos da Fundação Biblioteca Nacional (BN/Mss I-6,35,912) há o original manuscrito intitulado “Como o 'Homem' chegou de Manaus".

26 BARRETO, Lima. Diários íntimos. um longo sonho de futuro. Diários, cartas, entrevistas e confissões dispersas. op. cit. p. 120. 
excessos, às recomendações por moderação. Não por acaso, a terapêutica para essa etiologia indicava os purgativos: era preciso reequilibrar os líquidos e fluxos internos para se restabelecer a saúde.

Nova entrevista é feita em 22 de agosto de 1914, quando o paciente já parecia estar menos afetado pelos efeitos do álcool e, portanto, capaz de responder questões e "falar". Tanto que nos dados "comemorativos de família", Lima Barreto informa que "sua mãe morreu tuberculosa; o pai, vivo, goza saúde e é robusto. Tem três irmãos fortes”. Só depois relatou "que seu pai sofre neurastenia". O conceito teria sido introduzido por Beard, em 1867, e se referia a um "estado de exaustão nervosa", tendo como sintomas "fraqueza física e mental e um nervosismo generalizado". Nessa época, os "neurastênicos", como mostra Stelio Marras, acorriam às estações balneárias para que a terapêutica lá (incluindo ingestão de líquidos, as águas minerais) pudesse ajudar a refluir estados mórbidos, como esses nervosos, tal a neurastenia. Quem sabe o próprio estigma da cor já fosse entendido como uma composição mórbida de humores inatos, ao passo que o esforço da perfectibilidade se daria no sentido de reequilibrar esses humores. De toda maneira, a síndrome era entendida como a combinação de uma incapacidade de esforço físico associada a uma perturbação grave de humor. Irritação, cefaleia e distúrbios do sono, e uma dificuldade de adaptação social levavam à ocorrência de fobias e desconfiança generalizada.

Lima Barreto conhecia os conceitos em vigor, já que num primeiro momento omite a doença do pai, para depois reconhecer sua existência. Deveria estar a par, também, das teorias de hereditariedade e temer que a doença do pai fosse estigma forte a determinar suas próprias fraquezas. A tuberculose era igualmente entendida, nesse contexto, como estigma de raças degeneradas, marca pesada num exame de observação como esse. Mas falta introduzir "os comemorativos pessoais e de moléstias": "Nada informa aos antecedentes de hereditariedade. Acusa outros no rapto de manuscritos. Acusa insônias com alucinações visuais e auditivas. Estado geral bom e boa memória. Já teve sarampo e catapora, blenorragia, que ainda sofre e cancros venéreos". Pode-se imaginar a quantidade de situações vexatórias que o escritor tivera que enfrentar para lidar com essa parte do questionário. Insônias e alucinações eram sem dúvida efeitos passageiros do álcool e o escritor parecia não querer associar tais síndromes a qualquer herança biológica vinda do pai ou mesmo da mãe: sua "origem racial". Mas o literato precisou confessar mais: que tinha gonorreia e outras lesões venéreas, que eram sinônimo de vida desregrada, degenerada. Desregramento e degeneração aqui 
compreendidos como sintomas que expressam uma causa de fundo: o atavismo racial.

O laudo continua com Lima Barreto se confessando "alcoolista imoderado, não fazendo questão da qualidade". Comentava-se que o escritor era visto vagando pelas ruas do Rio, embriagado, com a roupa cada vez mais puída - um único terno azul e um chapéu cada vez mais amassado - e atuando de maneira inconveniente. Já era mesmo "imoderado" o seu uso do álcool. O cronista deve ter, porém, se destacado da média dos internos, já que o escrevente redigiu no seu laudo: ele "conhece e cita com bastante desembaraço fatos da história antiga, média, moderna e contemporânea, respondendo as perguntas que lhe são feitas prontamente. Têm noções de álgebra, geometria, geografia”. Fácil intuir o espanto do funcionário desavisado diante da erudição de Lima. Tanto que, nesse inquérito, o escrevente transcreve os autores prediletos do escritor: "Bossuet, Chateaubriand 'católico elegante' (sic), Balzac, Taine, Daudet". O paciente parece estar mais no controle da situação, tanto que o relator escreve que ele "conhece um pouco de francês e inglês", e que faz "comentários mais ou menos acertados" sobre os escritores que cita. E conclui: “em suma é um indivíduo que tem algum conhecimento e inteligente para o meio em que vive". No elogio, vem de carona o preconceito daquele que reconhece o conhecimento alheio, mas lhe concede apenas "tolerância", diante dos mais fracos e despossuídos.

A partir daí aparece um Lima Barreto um pouco delirante, misturando problemas de trabalho com receios diante de sua "fé anarquista". Quando perguntado sobre o motivo de sua internação, alegou que teriam "Ihe preparado uma assombração, com o aparecimento de fantasmas, que aliás lhe causavam muito pavor". Passou, logo a narrar um incidente junto ao Tenente Serra Pulquério, "seu amigo de pândegas", que o teria acusado de fazer panfletos contra seu trabalho. Depois de negar a necessidade da internação, o escritor afirmou que fora conduzido à polícia, "tendo antes cometido desatinos em casa, quebrando vidraças, virando cadeiras e mesas". Diz que teria sido convidado pelo comissário, que lhe teria dado domicílio, até que foi transferido para a clínica. Por isso "Protesta contra o seu 'sequestro', uma vez que nada fez que o justifique". Continua o relato afirmando que notara animosidade contra si, por parte dos companheiros de trabalho no Ministério da Guerra, e que temia represálias por adotar as doutrinas anarquistas. E assim vai se encerrando o depoimento, com as anotações do escrevente: "o paciente apresenta-se em geral calmo, só se exaltando quando narra motivos que justificaram sua internação". E anota: "Tem duas obras: Triste fim de Policarpo Quaresma e Memórias (sic) do escrivão Isaías Caminha”. 
É digno de destaque o fato de Lima Barreto oscilar entre momentos mais ou menos exaltados, mais conscientes ou por vezes delirantes. Mesmo em estado mais afetado, o seu trajeto anarquista deveria, nessa circunstância, trazer-lhe incômodo. Por isso, talvez, apesar de afirmar "não ser grande escritor, nem ótimo pensador", deve ter terminado seu relato, valendo-se de seu local na literatura, garantido por suas duas obras publicadas, que o escrivão pareceu solenemente desconhecer. A conclusão sobre a "moléstia" e seu "tratamento" é clara: alcoolismo se cura com purgativo e ópio, dois medicamentos ministrados para outros diagnósticos. Se tomarmos em conta a referida etiologia dos humores, veremos que as doenças, de modo geral, tinham esse fundo causal dos humores desequilibrados - e que, portanto, o genérico dos purgativos era a indicação médico-científica geral.

Todo esse ambiente ajuda a entender o sentimento de Lima, mais bem expresso em sua obra de ficção e escondido (mal escondido) em sua personagem Vicente Mascarenhas de Cemitério dos vivos. No capítulo em que ele entra no hospício pela mão da polícia, Lima descreve o pavilhão de observação, assim como emite juízo sobre as práticas de aprisionamento: "A polícia, não sei como e porquê, adquiriu a mania de generalizações e as mais infantis. Suspeita de todo o sujeito estrangeiro com nome arrevessado, assim os russos, polacos, romaicos são para eles forçosamente caftens; todo cidadão de cor há de ser por força um malandro, e todos os loucos hão de ser por força furiosos e só transportáveis em carros blindados" 27 . Tomar parte desse grupo era como viver "o espetáculo da loucura", comungar do "desatino dos loucos", ou reconhecer que no hospital "tudo é negro", por conta da "pigmentação negra de uma grande parte dos doentes... Negro é a cor mais cortante, mais impressionante...". Como conclui ele: esses eram "meus tristes companheiros de isolamento e de segregação social" 28 . De fato, "liberdade" parecia ter nada a ver com igualdade. Com certeza, nesse período ia ficando claro como a liberdade era negra, mas a igualdade, branca ${ }^{29}$.

27 BARRETO, Lima. Diário do hospício e O cemitério dos vivos. op. cit., p. 177-178.

28 Idem, p. 203, 210, 211 e 228.

29 Expressão usada pelo sociólogo Antonio Sergio Guimarães. 
Lima Barreto teve alta em 13 de outubro de 1914. Mas o círculo vicioso do álcool, dos delírios, das bagunças e das internações não pararia por aí. Em 25 de dezembro seria mais uma vez recolhido. Nova internação dar-se-ia entre dezembro de 1919 e fevereiro de 1920, nas duas vezes durante os festejos de Natal. Sua imagem é, porém, distinta da primeira vez. Resignado, ou buscando dessa vez permanecer anônimo (conforme declarou em entrevista concedida no hospício), Lima é outro na ficha.
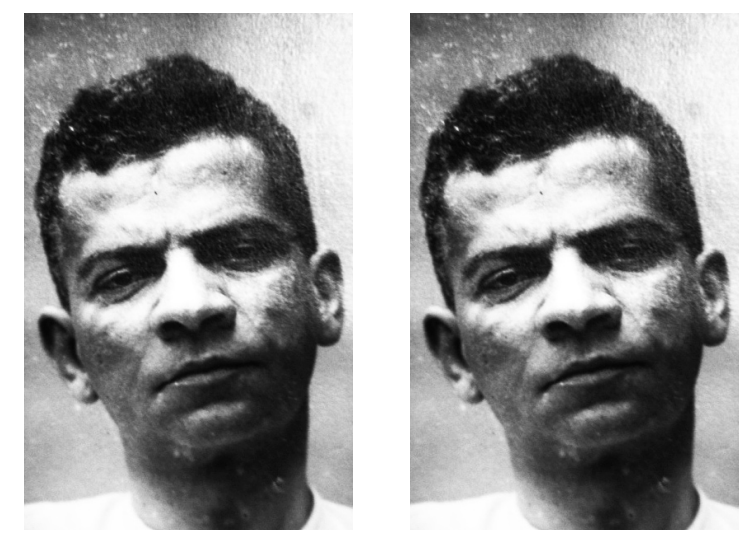

Nessa ocasião, o funcionário o caracteriza como pardo (e não branco); uma coloração mais escura, indefinida, como são os pardos: quase coringas da classificação. Quem sabe, por fim, nessa versão tão brasileira do racismo, em que se embranquece ou escurece dependendo da situação social, Lima Barreto tenha ficado "evidentemente" negro, ou melhor, pardo. Sua fisionomia, dessa vez, é conturbada e triste: cabeça deitada para o lado e expressão menos desafiante que a anterior. Parece um tanto vencido diante da evidência da doença, como se seu corpo desmentisse suas convicções profundas e contrárias às teorias deterministas sociais, realizando uma espécie de mímeses. Afinal, ainda em 1903, em seu Diário apresentava atitude irônica e crítica com relação à ciência, dizendo que ela não passava de "um ponto de vista sobre as cousas" ${ }^{1}$. Já o escritor de Diários do hospício é o que capitula e confessa seu fracasso ou autoexclusão: "Dormi em capinzais, fiquei sem chapéu,

zo BARRETO, Lima. O cemitério dos vivos. op. cit. p. 67.

31 BARRETO, Lima. Diários intimos: um longo sonho de futuro. Diários cartas, entrevistas e confissões dispersas. op. cit., p. 16. 


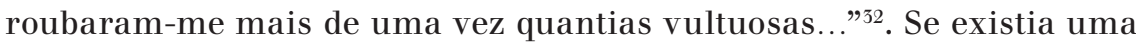
estratégia premeditada de inserção na história literária - em que o escritor manipulava cor, condição social, e região - nesse momento, a doença parece se constituir como a própria condição da memória.

Lima Barreto encontrava-se agora na Seção Calmeil, e na "Anamenese" o relator anota as seguintes informações. "O inspetor dessa Seção conheceu seu pai, que era administrador das colônias de Alienados da Ilha do Governador, São Bento e Conde Mesquita, ambas criadas em 1890. Informa que este senhor fazia uso excessivo de bebidas alcoólicas, apresentando humor irascível e taciturno. Consta-nos ainda que o progenitor do observado se acha agora em avançado estado de demência”. Como se vê, nessa segunda vez, o escrevente não se restringiu às informações dadas pelo interno. De posse de dados externos, ele faz alusões sobre a carga de hereditariedade negativa. Interessante, porém, é que o segundo parágrafo desmente o primeiro, com observações também retiradas de fora daquele contexto, mas atestando a importância do paciente como escritor: "O observador goza nos meios literários da reputação de um escritor talentoso e forte, cheio de mordacidade (...). Parece que nas palestras de café é o observado muito querido por seus ditos chistosos e picantes". Paradoxal como anamnese, o primeiro parágrafo condena, ao passo que o segundo concede. Mais uma vez o movimento, agora do escrivão, é duplo: identificação e sucessivo afastamento.

Os diários confirmam o estado do escritor nesse meio tempo. Em 3 de junho de 1917 escreve que havia passado "o mês entregue à bebida". Em 5 de setembro: "de há muito sabia que não podia beber cachaça. Ela me abala, combale, abate todo o organismo desde os intestinos até a enervação... No dia 30 de agosto eu ia a cidade, quando me senti mal. Tinha levado todo o mês a beber, sobretudo parati. Bebedeira sobre bebedeira, declarada ou não (...). Andei porco, imundo (...). Se não deixar de beber cachaça, não tenho vergonha. Queira Deus que deixe". A situação era declinante quando Lima Barreto é aposentado do serviço público, em 26 de dezembro de 1918. A partir daí começam seus Diários do hospício, cuja cronologia data justamente de $1919^{33}$.

De internação em internação o escritor parece se debater entre afirmar sua identidade combalida de intelectual de um lado, e o estigma

32 BARRETO, Lima. Diário do hospício e O cemitério dos vivos. op. cit., p. 69.

33 Não objetivo neste artigo aprofundar análise do Diário do hospício e muito menos do romance Cemitério dos vivos, que guarda aberto diálogo com ele, de maneira que ficção e não ficção se misturam. Estamos elaborando artigo para livro sobre autobiografias (com a coordenação de Sergio Miceli e Carlos Altamirano), quando nos deteremos sobre essas duas obras. 
da loucura, de outro. Diante do questionário, Lima Barreto omite, esquiva-se, não reage. Já fora do Hospital, e respaldado pelo terreno seguro da ficção, coloca na boca do seu personagem a reflexão que calou durante sua estadia no hospício. Critica a política de "antecedentes" e a ideia de que a origem dos pacientes é sempre reveladora de sua "herança de taras ancestrais". Nega a autoridade e o orgulho do médico que "despreza as observações dos leigos" e exerce sua profissão nesse "vago e nebuloso céu da loucura humana".

Nas páginas finais de Cemitério dos vivos, como num crescendo, ele chama aos loucos, e a ele próprio, de "rebotalhos da sociedade", "náufragos", e se pergunta, com um pingo de ironia: "A Constituição é lá para vocês?" ${ }^{4}$. Evidentemente não é possível olvidar que Nina Rodrigues, em seu livro A responsabilidade penal, a essas alturas propunha exatamente isso: a criação de uma sub-cidadania, uma cidadania menor, composta, nos termos de Lima, por "doentes indigentes e párias sociais" ${ }^{5}$. Submetido ao "convívio obrigado", conforme a própria definição, o escritor parece se conformar à "loucura e à degradação humana" ${ }^{56}$; lamenta não ter mais o "controle do próprio corpo" ${ }^{37}$, assim como reconhece que vai perdendo de lavada no jogo da cidadania: "Desde minha entrada na Politécnica venho caindo de sonho em sonho"s8.

O escritor morreria de enfarte, um pouco depois de escrever essas notas e os rascunhos do futuro livro. Saíra do trancamento no hospício para se resignar ao isolamento de sua biblioteca caseira. Um isolamento de um lado forçoso, de outro autoimposto pela tomada de consciência, mote da memória, de sua condição de preto, pobre, suburbano e louco. Cemitério dos vivos restaria sem um ponto final. Diferente de livros como Recordações do escrivão Isaías Caminha, Clara dos Anjos ou Triste fim de Policarpo Quaresma, que a despeito de serem igualmente biográficos, colocavam tudo na conta de um personagem ficcional e carregavam um projeto objetivo de denúncia da sociedade carioca e de suas práticas de exclusão; nesse caso, impõe-se a mímesis. Não por coincidência, em 1920, no jornal $A$ Folha, num texto chamado "O pistolão", tentou ainda desvencilhar sua pessoa de sua obra, dizendo que só se internara "para melhor observar o hospital e, assim, escrever um livro realista sobre o hospício". Derradeira estratégia; nessa hora ele já virara uma espécie de zona inclassificável: nem eu, nem outro.

34 BARRETO, Lima. Cemitério dos vivos. op.cit. p. 243, 244 e 245.

35 BARRETO, Lima. Diário do hospício e O cemitério dos vivos. op. cit., p. 245.

36 Idem. p 127 .

37 Idem. p. 246.

38 Idem. p. 83. 
Com certeza, não foi desejo de Lima Barreto publicar as notas dos seus diários, ou o romance apenas rascunhado, mas as duas obras de memória confirmam a impressão dos últimos tempos. Lima Barreto terminou confinado à imagem que ele próprio criou, entre o sacrifício e a redenção, entre o líder solitário de uma nova literatura e o alienado isolado em sua casa. Nesse caso, não só a loucura e a doença se intercalam, como o literato propositadamente rasura limites entre gêneros literários e sua própria condição. Não se sabe mais o que é conto, romance, diário ou até entrevista e ato premeditado. Memória representa aqui uma espécie de chancela desse ego aflitivo, exercício de dissimulação onisciente e oblíqua de um jogo complicado que mistura pobreza, cor, ambição, loucura. Deslocada, a frase que encerra a obra de ficção, derradeiramente interrompida, não poderia ser mais significativa: "Fiquei eu só no vão da janela".

Na crônica chamada "Da minha cela", publicada na A.B.C. de 30 de novembro de 1918, portanto, entre uma internação e outra, lembra das suas "mensurações": "Sofri também mensurações antropométricas e tive como resultado delas um pequeno desgosto, Sou branquicéfalo". Tal termo referia-se aos indivíduos que tinham o crânio alongado e de forma ovoide, e era com frequência associado aos tipos inferiores. Era claro que nesse texto a citação surgia como piada. Mas sabemos também que a graça da piada está no conjunto de alusões que ela apresenta ou esconde ${ }^{59}$. Nesse caso, a modernidade vinha como pedágio e negação. Negação da igualdade, do livre-arbítrio e da própria diferença.

39 Vide nesse sentido GEERTZ, Clifford. A interpretação das culturas. op. cit. 